\title{
The Integration of Physical Geography
}

\section{Andrew S. Goudie, Oxford}

\section{Introduction}

The purpose of this paper is to suggest that on the one hand Physical Geography is a broad-ranging discipline which should integrate the study of the various components that make up the environment, and that on the other it can integrate itself more squarely into the broader field of geography by demonstrating its relevance for understanding past, present and future changes in society and by showing its utility for humankind. This is an important issue for as BAUER (1999: 677) has written,

«the intellectual spaces separating the physical and human counterparts of Geography grow wider ... Substantive interdisciplinary conversations are becoming conspicuously silent at the crossroads of Geography.»

Physical Geographers are aware of this issue and, for example, have been exploring the relationship between Physical Geography and some of its component parts such as Hydrology (Hirschioeck 1999) and Climatology (CARLETon 1999). Mary Somerville's «Physical Geography», which was first published in 1848, was one of the earliest and most formative texts in Physical Geography. It gave a clear definition of the field, and demonstrated both the width of Physical Geography and its relationship to humans:

«Physical geography is a description of the earth, the sea, and the air, with their inhabitants animal and vegetable, of the distribution of these organized beings and the causes of that distribution ... man himself is viewed but as a fellow-inhabitant of the globe with other created things, yet influencing him to a certain extent by his actions and influenced in return. The effects of this intellectual superiority on the inferior animals, and even on his own condition, by the subjection of some of the most powerful agents in nature to his will, together with the other causes which have had the greatest influence on his physical and moral state, are among the most important subjects of this science.»

The cohesion and range of Physical Geography in the Anglo-Saxon world declined in the twentieth century, however, for it was dominated for much of the time by Geomorphology. As STODDART (1987) remarked about the British situation during the inter-war years, «in research, if not teaching, "physical geography» meant geomorphology: for while some attention was given to meteorology, climatology and to some extent pedology and biogeography, it was on the level of elementary service courses for students rather than as a contribution to new knowledge».

Moreover, with the demise of environmentalism from the 1920s onwards, many geographers eschewed environment-human considerations.

In contrast to the view of Somerville, Physical Geography books tended increasingly to ignore human impact and environmental influences. So, for example, Birot (1966) saw Physical Geography as the study of «the visible surface of natural landscapes as they would appear to the naked eye of an observer travelling over the globe before the interaction of mankind.»

Physical Geography possibly reached its low point in the late 1960s and early 1970s when spatial modellers, particularly of urban systems, saw little room for it within Geography. Even some Physical Geographers doubted its role in a world where regional differences were seen to be declining and where many people, especially in cities, were thought to be coming progressively divorced from the reality of their immediate physical surroundings (CHORLEY 1971).

The state of Physical Geography at this time can be illustrated by a consideration of one of the most used textbooks in Britain over this period - F.J. MonKHOUSE's "The Principles of Physical Geography». Its first edition appeared in 1954 and thereafter it was used intensively for the next quarter of a century, with an eighth edition appearing in 1975. What were its main characteristics? First of all, in spite of its title, there is scant consideration of the principles that underlie Physical Geography and of what the sub-discipline aims to do. There is very little concern with theory, ideas, the airing of controversy and intellectual constructs like models. It is very strong on description and classification. With the exception of some of its discussion of climate, there is no concern with systems or with such phenomena as biogeochemical or nutrient cycles. The work is largely unconcerned with ecological approaches and so there is very little attempt at integrating the different components of Physical Geography. It is almost entirely qualitative, containing not one scientific formula. It is extraordinarily weak on drainage basin processes, which could have provided one means of integration (CHORLEY 1969). It was written a decade before the development of the plate tectonics paradigm and so it lacks this important integrating concept as well. There

Der vorliegende Beitrag war Thema des Symposiums «Anwendung und Perspektiven einer integrativen Wissenschaft» anlässlich des 60. Geburtstages von Prof. Dr. Dr. h.c. Hartmut LESER, veranstaltet am 2. Dezember 1999 in Basel. 
is also remarkably little on environmental change, whether natural (e.g. the glacial and interglacial cycles of the Pleistocene, neoglaciations of the Holocene, ENSO events) or anthropogenic. Humans seldom rear their heads and so there is limited concern with hazards, resources, environmental management or the application of Physical Geography to societal needs.

MONKHOUSE was by no means unique at this time, and a similar analysis could be done for almost all contemporary texts.

\section{More recent trends}

The modern genre of Physical Geography text is remarkably different from MONKHOUSE and his contemporaries, not least because most have the word «environment» squarely in their titles (e.g. De BLJI \& Muller 1996; Park 1997; Briggs et al. 1997). An early attempt to review trends was made in the mid-1980s by GREGory (1985). For the period from 1950 to 1970 he identified five main developing themes: quantification, Quaternary studies, process studies, studies that recognized the importance of human activities, and the systems approach. For the period from 1970 to 1980 he selected two further trends: a concern with time, which involved such issues as thresholds and complex responses; and an increasing tendency towards the application of Physical Geography to solving environmental problems. Additionally, for the late 1980s he drew attention to the burgeoning role of remote sensing and information technology.

Since Gregory wrote, there are many signs that Physical Geography has become concerned increasingly with certain key themes: the human impact, natural environmental change, the application of Physical Geography, environmental management and the integration of the various elements of Physical Geography and their linkage to social forces.

\section{The human impact}

Earlier generations of Physical Geographers often appear to have avoided areas that were palpably affected by human activity. They sought natural and largely undisturbed areas in which to base their research. Since then, there has been a growing awareness that such pristine or wilderness areas are increasingly atypical of the world as a whole, and that the impacts that humans are having deserve study in their own right (Goudie 1993, 1999a). Indeed, there are those who feel that as the subject straddling the human-environment ecotone, Geography should be actively concerned with human impact, its history and management. Many of the great issues that face the world today require a geographical treatment, including acid depo- sition (BATTARbeE et al. 1988), forest decline (INNes 1992), desertification (Thomas \& Middleton 1994), deforestation (Williams 1989), wetland loss (Maltby 1986), salinity problems (Goudie \& VILES 1997) and global climate change, be it cumulative or systemic. At the same time there is a growing appreciation that the study of environmental history has much to tell us about environmental change (SImmons 1993; R.H. Grove 1997), and some of the most powerful studies in Geography have been those that have looked at long-term land-scape change in the context of human history (e.g. MorTIMORE 1989; Tiffen et al. 1994). There has been an increasing desire to establish the relative importance of human actions and natural processes in causing environmental changes such as gully initiation (e.g. WeLls 1993).

\section{Natural environmental change and its consequences}

Another major theme of contemporary Physical Geography is natural environmental change. It is remarkable, but partly uncoincidental, that at the same time that scientists have been concerned with anthropogenic impacts on the environment, they have also become increasingly aware of the abruptness, frequency, magnitude and consequences of natural changes at a whole range of temporal scales. Much of the reason for this concern arises from the development in the last four decades of new technologies for dating and environmental reconstruction, including the coring of ocean floors, peat deposits, lakes and ice sheets (Lowe \& WALKER 1997). Some of these techniques, including optical dating, have been adopted with enthusiasm by Physical Geographers (e.g. Stokes 1999). We now appreciate that short term events like the Little Ice Age (J.M. Grove 1988, 1997) had profound implications for human societies, and that the abruptness of phases like the Younger Dryas (ANDERson 1997) may have made them especially significant for prehistoric groups. Indeed, natural environmental changes are of immense potential significance for interpreting human history and prehistory (Goudie 1999b). This is evident when one considers the history of the Sahara in the Holocene.

At the Kharga Oasis in the Western Desert of Egypt, there are immense lake and tufa deposits around which Neolithic tools have been found in great profusion. They indicate the existence of higher groundwater levels and a considerable human population. The Neolithic pluvial was a time that was particularly favourable for human activities in the region (CATONTHOMPSON 1952). A good example of mid-Holocene humidity in the hyper-arid heart of the Eastern Sahara is provided by Ritchie \& HaYNes (1987). Their pollen spectra for Oyo, dating from c. 8500 years BP (before present) until around $6000 \mathrm{BP}$, show that there were 
strong Sudanian elements in the vegetation, and they identified pollen of tropical taxa such as Hibiscus. During this phase, Oyo must have been a stratified lake surrounded by savanna vegetation similar to that now found $500 \mathrm{~km}$ further south. After $6000 \mathrm{BP}$ the lake became shallower and thorn and scrub grassland replaced the sub-humid savanna. At around 4500 $\mathrm{BP}$ the lake dried out, aeolian activity returned and vegetation disappeared except in wadis and oases. In effect we see the Sahara disappearing as an hyper-arid environment, becoming a favourable environment for human activities (Petit-Maire 1989; Roberts 1989) and then desiccating once again. The remarkable blossoming of archaeological sites and lake deposits in the Sahara at $8000 \mathrm{BP}$ is testified to by an abundance of mortars and grinders (indicating grass cover), and of hooks and harpoons (indicating lakes and fishing therein). Sites became much rarer after $6000 \mathrm{BP}$ as the climate deteriorated (PETIT-MAIRE et al. 1997).

A further climatic deterioration around 4000 years ago could be involved in the near simultaneous but mysterious collapse or eclipse of advanced civilizations in Egypt, Mesopotamia and north west India (DALfEs et al. 1997).

While we may no longer accept some of the rather crude attempts that were developed by the environmental determinists in the first decades of the twentieth century to relate climatic changes to events in history and prehistory, we now have a range of techniques for both dating and for environmental reconstruction about which they could only have dreamed. Using them, there is therefore a need to revisit many great themes (some of which are discussed by VRBA et al. 1995 and in SLACK 1999), including hominid emergence, the diffusion of humans out of Africa, hiatuses in dryland and cold climate prehistory, and the origin and timing of domestication. As SherRATt (1997: 283) has pointed out,

«Environmental change is not simply a backdrop to evolution: it is a principal reason for major episodes of biological change».

Such biological changes include human evolution and the domestication process.

\section{The application of Physical Geography to societal needs}

In recent years increasing attention has been paid to the application of Physical Geography to the needs of society (Jones 1980; CoOKe \& Doornkamp 1992). Environmental management has become a major field in many branches of Physical Geography (O'RIORDAN 1995), including the management of water resources (BEAUMONT 1988; JoNes 1997), water pollution (BurT et al. 1993), and coasts (VILES \& SPENCER 1995; BIRD 1996). There have also been many contributions to the study of environmental hazards (JoNEs 1993; SмITH 1992) and disasters (AleXANDER 1993). In some cases this has involved a consideration of societal issues, including vulnerability (e.g. CHESTER 1993).

A consideration of the role of the applied geomorphologist (Table 1) demonstrates some of our skills, and as GoudiE (1994) showed, applied geomorphologists undertake a range of tasks. These include the mapping of hazards and resources, identifying the rates at which change is taking place, assessing the causes of observed changes, placing engineering schemes within their environmental context, and looking at the consequences of human attempts at environmental management.

\section{Integration and conclusion}

Although in common with much science Physical Geography has tended to move towards increasing reductionism and specialisation, it has, paradoxically, also displayed an increasing tendency to try and integrate its different components. This may either be because of the deliberate adoption of systems thinking (CHORLEY \& KENNEDY 1971), which by its very nature focuses on inter-relationships, or it may be partly as a result of an increasing concern with ecological approaches, or

- Mapping of landforms to find hazardous sites, mineral

resources and to describe physical habitat

- Mapping of other phenomena (e.g. soils) through their association with landform elements

- Identifying rates of change of hazardous phenomena through direct monitoring, use of sequential maps, air photos, remote sensing images, studies of archival information, etc.

- Identifying causes of changes and hazards and predicting and modelling future hazards

- Undertaking post-event surveys of major hazardous events

- Untertaking pre-construction environmental impact assessments and post-construction surveys of major engineering projects

- Devising management solutions to geomorphological problems and involvement with policy

Table 1: The nature of Applied Geomorphology Das Wesen der Angewandten Geomorphologie La nature de la géomorphologie appliquée 
because of a realisation that many of the most rewarding and challenging intellectual developments occur when, for example, earth scientists and life scientists get together, or indeed, geomorphologists and biogeographers (VILEs 1988; ThORNES 1990). There is, as BAUER et al. (1999: 778) points out, a tension between integrative and reductionist tendencies that is often inextricably linked to issues of scale. On the one hand, most Physical Geographers have had a «decades-long addiction to reductionism" and on the other «such reductionism flies in the face of our geographic traditions and roots.»

However, perhaps a major reason for the integrative tendencies has been the resurgence of Biogeography, which for too long, with Climatology, was one of the less vibrant parts of the discipline. We now see a range of texts that attempt to give an integrated view of landscape types as diverse as oceanic islands (NUNN 1994), caves (GILLIESON 1996), and rainforests (MILLINGTON et al. 1995), while others survey whole continents (e.g. Adams et al. 1996). Likewise, exciting developments are taking place in our understanding of savanna biomes through an increasing concern with such forces as forest fires (natural and human induced), herbivores, soil characteristics and the history of land use (see, for example, FaIRHEAD \& LEACH 1997). One of the major thrusts for integration has come from the continent of Europe in the shape of Geoecology and Landscape Ecology. The former attempts to give a greater emphasis to abiotic components than the latter, but as HugGeTr (1995) indicates, the two are essentially the same. The term Landscape Ecology was devised by Troll $(1939,1971)$, and as NAVeH \& LieberMAN (1984:3) wrote,

«Landscape ecology is a young branch of modern ecology that deals with the interrelationship between man and his open and built-up landscapes...landscape ecology evolved in central Europe as a result of the holistic approach adopted by geographers, ecologists, landscape planners, designers and managers in their attempt to bridge the gap between natural, agricultural, human and urban systems".

Likewise, VINK (1983: 2) saw it as

"the study of the relationship between phenomena and processes in the landscape or geosphere including the communities of plants, animals and man",

while Forman \& Godron (1986: 595) saw it as "the study of the structure, function and change in a heterogeneous land area composed of interacting ecosystems".

Remote sensing and GIS enable the collection and analysis of spatial data relating to landscapes and their components (HAINES-Young et al. 1993) and Landscape Ecology has much to contribute to the development of conservation and Biogeography (KUPFER 1995). One notes with particular appreciation the many contributions that LESER has made to the development and application of Landscape Ecology (e.g. LeSER 1983, 1997).
Building upon some of the tendencies outlined in this paper, Slaymaker \& SPENCER (1998: 7) have proposed the redefinition of Physical Geography so that it is redirected from an emphasis on

"the pot-pourri of information about the Earth and its atmosphere to a coherent integrating theme of global environmental change».

They believe that to achieve that goal, Physical Geography should be concerned with three crucial themes: identifying, describing and analysing the distribution of biogeochemical elements in the environment; interpreting environmental systems at all scales, both spatial and temporal, at the interface between atmosphere, biosphere, hydrosphere, lithosphere and society, and; determining the resilience of such systems in response to perturbations, including human activities. They also argue that a commitment to the understanding of human-environmental linkages is crucial to the sustainability of our planet and that this should be the mandate for Physical Geography in the $21^{\text {st }}$ century. Global change is indeed a crucial area for geographical endeavour and geographers need to identify the likely impacts of change on ecosystems, to identify especially sensitive locations or «hotspots» (Goudie 1996), and to assess the most appropriate means of environmental management in an ever changing world.

\section{Literature Cited}

Adams, W., Goudie, A.S. \& A.R. Orme (1996): The Physical Geography of Africa. - Oxford: Oxford University Press.

Alexander, D. (1993): Natural Disasters. - London: UCL Press.

Anderson, D. (1997): Younger Dryas research and its implications for understanding abrupt climatic change. - In: Progress in Physical Geography 21 (1): 230-249.

BattarbeE, R. \& 15 Collaborators (1988): Lake Acidification in the United Kingdom 1800-1986. - London: Ensis.

BAuer, B.O. (1999): On methodology in physical geography. Current status, implications, and future prospects. - In: Annals of the Association of American Geographers 89: 677-679.

BAuer, B.O., Winkler, J.A. \& T.T. Veblen(1999):Afterword: a shoe for all occasions or shoes for every occasion: methodological diversity, normative fashions, and metaphysical unity in physical geography. - In: Annals of the Association of American Geographers 89: 771-778.

Beaumont, P. (1988): Environmental Management and Development in Drylands. - London: Routledge.

BIRD, E.C.F. (1996): Beach Management. - Chichester: Wiley.

Birot, P. (1966): General Physical Geography. London: Harrap.

Briggs, D., Smithson, P., Atkinson, K. \& K. Addison 
(1997): Fundamentals of Physical Geography Environment. - London: Routledge.

Burt, T.P., Heathwaite, L. \& S.T. Trudgill (eds) (1993): Nitrates: Processes, Patterns and Control. Chichester: Wiley.

CARLeton, A.M. (1999): Methodology in climatology. - In: Annals of the Association of American Geographers 89: 713-735

Caton-Thompson, G. (1952): Kharga oasis in Prehistory. - London: Athlone Press.

Chester, D. (1993): Volcanoes and Society. - London: Arnold.

Chorley, R.J. \& B.A. Kennedy (1971): Physical Geography: A Systems Approach. - London: Methuen.

Chorley, R.J. (ed.) (1969): Water, Earth and Man. London: Methuen.

CHORLEY, R.J. (1971): The role and relations of physical geography. - In: Progress in Geography 3: 87-109.

COOKE, R.U. \& J.C. DooRnKAMP (1992): Geomorphology in Environmental Management ( $2^{\text {nd }}$ edition). Oxford: Oxford University Press.

Dalfes, H.N., Kukla, G. \& H.Weiss (eds.) (1997): Third Millennium BC Climate Change and Old World Collapse. - Berlin: Springer Verlag.

De BliJ, H. \& P.O. Muller (1996): Physical Geography of the Global Environment. - New York: Wiley.

FAIRHEAD, J. \& M. LEACH (1997): Misreading the African Landscape. - Cambridge: Cambridge University Press.

Forman, R.T. \& M. Godron (1986): Landscape ecology. - New York: Wiley.

Gillieson, D. (1996): Caves. - Oxford: Blackwell.

Goudie, A.S. (1993): Human influence in geomorphology. - In: Geomorphology 7: 37-59.

GouDIE, A.S. (1994): The nature of physical geography: a view from the drylands. - In: Geography 79: 194-209. GoudIE, A.S. (1996): Geomorphological «hotspots» and global warming. - In: Interdisciplinary Science Reviews 21:253-9.

Goudie, A.S. (1999a): The Human Impact on the Natural Environment (5 $5^{\text {th }}$ edition). - Oxford: Blackwell.

Goudie, A.S. (1999b): The Ice Age in the tropics and its human implications. - In: SLACK, P. (ed.): Environments and Historical Change. - Oxford: Oxford University Press: 10-45.

Goudie, A.S. \& H. VILES (1997): Salt Weathering Hazards. - Chichester: Wiley.

Gregory, K.J. (1985): The Nature of Physical Geography. - London: Arnold.

Grove, J.M. (1988): The Little Ice Age. - London: Routledge.

Grove, J.M. (1997): The century time-scale. - In: T.S. Driver \& G.P. Chapman (eds): Time-Scales and Environmental Change. - London: Routledge: 39-87.

Grove, R.H. (1997): Ecology, Climate and Empire: Colonisation and Global Environmental History, 1400-1940. - Cambridge: White Horse.
Haines-Young, R., GreEn, D.R. \& S.H. Cousins (eds) (1993): Landscape ecology and GIS. - London: Taylor and Francis.

HiRschboeck, K.K. (1999): A room with a view: some geographic perspectives on dilettantism, cross-training, and scale in hydrology. - In: Annals of the Association of American Geographers 89: 696-706.

Huggetr, R.J. (1995): Geoecology. An evolutionary approach. - London: Routledge.

INNES, J. (1992): Forest decline. - In: Progress in Physical Geography 16: 1-64.

JONES, D.K.C. (ed.) (1993): Environmental hazards: the challenge of change. - In: Geography 78: 161-198.

JONES, D.K.C. (1980): British applied geomorphology: an appraisal. - In: Zeitschift für Geomorphologie NF, Supplementband 36: 48-73.

JoNES, J.A.A. (1997): Global Hydrology: Processes, Resources and Environmental Management. - Harlow: Longman.

KUPFER, J.A. (1995): Landscape ecology and biogeography. - In: Progress in Physical Geography 19: 18-34.

LESER, H. (1983): Geoökologie. - In: Geographische Rundschau 35:212-221.

LESER, H. (1997): Landschaftsökologie:Ansatz, Modelle, Methodik, Anwendung. - Stuttgart: Eugen Ulmer.

LOWE J. \& M. WALKER (1997): Reconstructing Quaternary Environments ( $2^{\text {nd }}$ edition). - Harlow: Longman.

MaltBY, G. (1986): Waterlogged Wealth: Why Waste the World's Wet Places. - London: IIED.

Millington, A.C., Thompson R.D. \& A.J. Reading (1995): Humid Tropical Environments. - Oxford: Blackwell.

Monkhouse, F.J. (1954): Principles of Physical Geography. - London: Hodder and Stoughton.

Mortimore, M. (1989): Adapting to Drought: Farmers, Famines and Desertification in West Africa. - Cambridge: Cambridge University Press.

Naven, Z. \& A.S. Lieberman (1984): Landscape ecology. Theory and application. - New York: SpringerVerlag.

NunN, P.D. (1994): Oceanic Islands. - Oxford: Blackwell.

O'Riordan, T. (ed.) (1995): Environmental Science for Environmental Management. - Harlow: Longman Scientific and Technical.

PARK, C. (1997): The Environment: Principles and application. - London: Routledge.

Petit-Maire, N. (1989): Interglacial environments in presently Hyperarid Sahara: paleoclimatic implications. - In: Leinen, M. \& M. Sarnthein (eds): Paleoclimatology and Paleometereology: Modern and Past Patterns of Global Atmospheric Transport. - Dordrecht: Kluwer: 637-661.

Petit-Maire, N., Benfort, L. \& N. Page (1997): Holocene climate change and man in the present day Sahara desert. - In: Dalfes, H.N., Kukla, G. and H. WeIss (eds): Third Millennium BC Climate Change 
and the Old World Collapse. - Berlin: Springer Verlag: 297-308.

Ritchie, W. \& C.V. Haynes (1987): Holocene vegetation zonation in the Eastern Sahara. - In: Nature 330: 645-7.

Roberts, N. (1998): The Holocene (2 ${ }^{\text {nd }}$ edition). Oxford: Blackwell.

Sherratr, A. (1997): Climatic cycles and behavioural revolutions: the emergence of modern humans and the beginning of farming. - In: Antiquity 71:271-87.

Simmons, I.G. (1993): Environmental History: A Concise Introduction. - Oxford: Blackwell.

SlaCK, P. (ed.) (1999): Environments and historical change. - Oxford: Oxford University Press.

Slaymake, R.O. \& T. Spencer (1998): Physical Geography and Global Environmental Change. - Harlow: Longman.

Smith, K. (1992): Environmental Hazards: Assessing Risk and Reducing Disaster. - London: Routledge.

Somerville, M. (1848): Physical Geography. - London: Murray.

STODDART, D.R. (1987): Geographers and geomorphology in Britain between the wars. - In: R.W. STEeL (ed.): British Geography 1918-45. - London: Institute of British Geographers: 156-176.

STOKES, S. (1999): Luminescence dating applications in geomorphological research. - In: Geomorphology 29: 153-171.

Thomas, D.S.G. \& N.J. Middleton (1994): Desertification: Exploding the Myth. - Chichester: Wiley.

Thornes, J. (ed.) (1990): Vegetation and Erosion. Chichester: Wiley.

Tiefen, M., Mortimore, M. \& F. Gichuki (1994): More People, Less Erosion. - Chichester: Wiley.

TROLL, C. (1939): Luftbildplan und ökologische Bodenforschung. - In: Zeitschrift der Gesellschaft für Erdkunde zu Berlin: 241-298.

TroLl, C. (1971): Landscape ecology (geoecology) and biogeocenology - a terminological study. - In: Geoforum 8: 43-46.

VINK, A.P.A. (1983): Landscape ecology and land use. - London and New York: Longman.

Viles, H.A. (ed.) (1988): Biogeomorphology. - Oxford: Blackwell.

Viles, H.A. \& T. Spencer (1995): Coastal Problems. London: Arnold.

Vrba, E.S., Denton, G.H., Partridge, T.C. \& L.H. BuRKLE (eds) (1995): Paleoclimate and Evolution with Emphasis on Human Origins. - New Haven: Yale University Press.

Wells, N.A. (1993): The initiation and growth of gullies in Madagascar: are humans to blame? - In: Geomorphology 8: 1-46.

Williams, M. (1989): Americans and their Forests: A Historical Geography. - Cambridge: Cambridge University Press.

\section{Summary: The Integration of Physical Geography}

Physical Geography has in recent years developed certain tendencies which have led to a greater coherence and to a greater degree of integration with the rest of Geography. Of particular importance are studies of the human impact, of environmental change and its impacts, of the application of Physical Geography to societal needs, of Geoecology and Landscape Ecology, and of global change.

\section{Zusammenfassung: Die Integration der Physischen Geographie}

Die Physische Geographie hat in den vergangenen Jahren Tendenzen entwickelt, die zu einer grösseren Kohärenz und einer stärkeren Integration mit der übrigen Geographie geführt haben. Von besonderem Interesse sind Studien über die Einwirkungen des Menschen auf die Umwelt, über Umweltveränderungen und deren Auswirkungen, über die Anwendung der Physischen Geographie auf gesellschaftliche Anforderungen, über Geoökologie und Landschaftsökologie sowie globalen Wandel.

\section{Résumé: L'intégration de la géographie physique}

Ces dernières années, la géographie physique a développé certaines tendances qui l'ont conduite à davantage de cohérence et à un plus haut degré d'intégration avec le reste de la géographie. L'impact humain, les changements environnementaux et leurs incidences, l'application de la géographie physique aux besoins de la société, la géoécologie et l'écologie du paysage ainsi que le changement global sont des sujets d'étude particulièrement importants.

Prof. Dr. Andrew S. Goudie, School of Geography and the Environment, University of Oxford, Mansfield Road, Oxford, OX1 3TB, UK.

e-mail: andrew.goudie@geog.ox.ac.uk 